\title{
Paradigma Maqāsid Syariah Menjadi Disiplin Ilmu
}

\author{
Muh. Mukhlish Abidin \\ STAI Al-Husein Magelang \\ nihaie20@yahoo.com
}

\begin{abstract}
The focus of this paper is on the issue of maqasid sharia from the historical aspect and the paradigm shift in thinking from scientific disciplines that still belong to Ushul Figh to become independent disciplines. Maqasid sharia is an attempt to harmonize commands and prohibitions to produce a moderate attitude in capturing messages from religious texts born 14 centuries ago. Maqasid sharia was established as a new independent scientific discipline after the appearance of as-Syatibi, which was later developed by scientists after a change of approach (which was previously only a figh approach in the modern approach to maqasid science with multiple disciplines including medical, social and any other sciences which support to take legal conclusion). Maqasid sharia is wisdom from what Allah revealed about law to be made a universal value.
\end{abstract}

Keywords: Paradigm, maqāsid syariah and disciplines

\begin{abstract}
Abstrak
Fokus dari makalah ini adalah pada masalah maqasid syariah dari aspek historis dan pergeseran paradigma dalam berpikir dari disiplin ilmu yang masih milik Ushul Fiqh untuk menjadi disiplin ilmu yang independen. Maqasid syariah adalah upaya untuk menyelaraskan perintah dan larangan untuk menghasilkan sikap moderat dalam menangkap pesan dari teks-teks agama yang lahir 14 abad yang lalu. Maqasid syariah didirikan sebagai disiplin ilmu independen baru setelah munculnya as-Syatibi, yang kemudian dikembangkan oleh para ilmuwan setelah perubahan pendekatan (yang sebelumnya hanya pendekatan figh dalam pendekatan modern untuk ilmu maqasid dengan berbagai disiplin ilmu termasuk kedokteran, sosial dan ilmu lain yang mendukung untuk mengambil kesimpulan hukum). Maqasid syariah adalah kebijaksanaan dari apa yang Allah ungkapkan tentang hukum untuk dijadikan nilai universal.
\end{abstract}

Kata kunci: Paradigma, maqāsid syariah dan disiplin ilmu

\section{PENDAHULUAN}

Tantangan globalisasi dan modernisasi tidak bisa terelakkan, sejalan dengan laju perkembangan zaman yang semakin canggih, karena didukung dengan perkembangan ilmu pengetahuan dan teknologi, sebagai konsekuensi dari pesatnya perkembangan zaman terjadinya perubahan sosial di masyarakat secara cepat dan massive, sehingga dapat menimbulkan persoalan-persoalan baru yang membutuhkan jawaban dan solusi secara cepat dan tepat. Persoalan yang timbul di masyarakat tidak bisa begitu saja diabaikan terutama bagi para ulama dan agamawan yang selalu berinteraksi dengan masyarakat, salah satu tuntutan masyarakat antaranya; agama harus mampu memberikan jawaban bagi masyarakat 
terhadap permasalahan yang sedang dihadapinya, terutama pada masyarakat yang menjunjung nilai-nilai agama sebagai dasar dalam segala lini kehidupan.

Diskursus tentang perubahan dan perkembangan zaman tidak boleh lepas dari agama dalam artian agama harus mampu memberikan inspirasi dalam proses perubahan dan modernisasi, jangan sebaliknya (agama sebagai penghambat dari proses perkembangan zaman), tanggung jawab ulama dan kaum agamawan dalam upaya merelevansikan ajarannya dengan masa sekarang sangat diharapkan, sehingga kehadiran agama mendapat sambutan masyarakat, karena mampu memberikan jawaban dan solusi dari permasalahan. Teks-teks keagamaan yang lahir dari berabad-abad silam secara sosial-kultural sangat berbeda dengan masa sekarang, sehinga membutuhkan penafsiran baru dengan pendekatan dan metodologi yang juga baru, pendekatan dan metode baru diharapkan mampu menterjemahkan pesan-pesan agama dengan baik dan tepat, sehingga relevan dan diterima oleh masyarakat modern.

Tek-teks agama yang muncul pada 14 abad silam, tentu memiliki keterbatasan dan ketidaksesuaian dengan realita sekarang yang sedang dihadapi, karena permasalahan yang dihadapi umat senantiasa berkembang seiring dengan perkembangan zaman dan peradaban. Perlunya perangkat metodologi dan pendekatan yang baru, sebagai upaya menyelaraskan pesan dan doktrin keagamaan di era-pengetahuan dan teknologi.

Upaya merelevansikan teks-teks keagamaan yang muncul pada 14 abad silam ke masa sekarang banyak ilmuan atau ulama menawarkan metodologi dalam penafsiran tek-teks keagamaan, salah satu tawarannya yaitu: teori Maqāsid al-Syari'ah, (sebuah perangkat metodologi yang berusaha menghadirkan hukum yang tersebar dalam teks-teks keagamaan untuk direlevansikan dalam realita kehidupan modern dengan mengambil pesan atau nilai-nilai universal). Berdasarkan uraian tersebut diatas peneliti ingin terfokus dalam pembahasan tentang paradigma Maqāsid al-Syariah sejak awalmula tumbuh berkembang sehingga menjadi sebuah disiplin ilmu tersendiri, permisalan ilmu Maqāsid al-Syari'ah dengan disiplin ilmu lainnya yang berkembang dalam khasanah peradaban islam, bagaikan benih atau biji yang telah disebar dan tertanam pada masa rasul, akan tetapi kemunculan dan tumbuh kembangnya tidak seperti tumbuhan kembangnya biji lainya (ilmu-ilmu keislaman yang tumbuh dengan pesat). Sehingga ilmu Maqāsid al-Syari'ah terbilang sebagai ilmu yang langka atau ilmu baru karena mengalami perkembangan yang lambat. 


\section{KAJIAN LITERATUR}

Tujuan diturunkanya Syari'at islam untuk mewujudkan kemaslahatan bagi umat manusia dan semesta alam (rahmatan lil ālamīn). Syari'at yang diturunkan oleh Allah Swt termaktub dalam al-Qur'an dan al-Sunnah, yang terdiri dari unsur perintah dan larangan. Perintah Allah Swt dalam al-Qur'an dan al-Sunah selalu berorientasi pada peribadatan atau ibadah, sedangkan larangan dalam al-Qur'an dan al-Sunah akan selalu berorientasi dalam hal muamālāh (interaksi dan pergaulan dalam kehidupan). Antara perintah dan larangan tidak bisa berjalan sendirisendiri sehingga harus ada jembatan penghubung antar keduanya untuk menghindari dari perbuatan ifrät (berlebih-lebihan dalam hukum) dan tafrit (perbutan meremehkan dalam hukum) dalam memaknai atau menafsirkan al-Qur'an dan al-Sunnah, sehingga bisa menumbuhkan sikap tawasut (moderat) dalam pengamalan beragama dan lebih bisa fleksible, mampu menunjukkan islam shālih likullì zamān wā makan. (Syatibi al2001).

Untuk mewujudkan itu semua dibutuhkan perangkat metodologi atau pengetahuan yang mampu membantu manusia untuk mentrasformasikan teks-teks masa lalu ke zaman sekarang, dalam mewujudkan usaha tersebut sebagian ulama menawarkan Maqāsid alSyari'ah sebagai perangkat yang mampu menjembatani dan mengharmonisasi antara perintah dan larangan, sehingga hukum tidak dipandang kaku atau dengan perangkat baru ini hukum lebih fleksible.

Maqāsid al-Syari'ah terdiri dari dua suku kata yaitu: Maqāsid dan Syari'ah dari penggabungan antara keduanya menjadi istilah Maqāsid alSyari'ah. Kata Maqāsid menunut ibn Mandhur dalam kitabnya Lisānul

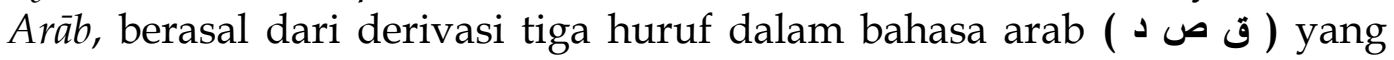
memiliki beragam arti antaranya: tujuan, menghadap, obyek atau sasaran, istiqamah, tempat sandaran, adil atau moderat, dekat, sesuatu yang berhubungan dengan niat dan jalan yang lurus. (Mandhur 1998) sedangkan pemaknaan dari kata tersebut harus menyesuaikan dengan teks dan memiliki ketergantungan dengan kontek dalam pemakaian kata. secara terminologi Maqāsid adalah segala yang diperintahkan oleh Allah Swt atau segala perintah Allah Swt mengandung hikmah dan kemaslahatan bagi manusia baik di dunia maupun di akhirat. (Ahmad 2000). Sedangkan kata al-Syari'ah diambil dari al-Quran yang pengulanganya (pengulangan lafadz al-Syari'ah sebanyak lima kali), secara harfiyah memiliki arti jalan yang lurus, metode atau cara, ajaran, agama, terusan tempat air mengalir. (Mandhur 1998) Sedangkan makna secara terminologi al-Syari'ah adalah segala yang disyari'atkan oleh Allah Swt mencakup hukum dan keyakinan atau aqidah yang akan menghantarkan orang yang meyakininya dan mengamalkanya kepada kebahagiaan dunia dan akhirat. (Alim al- 1991) 
Makna Maqāsid al-Syari'ah secara terminologi dalam literatur ulama usul fikih dan fikih terdahulu tidak dijumpai, sampai muncul imam alGhazali (505 H.) yang menggunakan istilah Maqāsid al-Syari'ah dalam kitabnya al-Mustasfā pada pembahasan maslahāh dan madharāt, walaupun pemakaianya sudah ada pada abad kelima Hijriyah tetapi tidak menggunakan lafadz Maqāsid al-Syari'ah secara tersurat yaitu dengan menggunakan lafadz "Maqsūd Syar'i". (Miftah al- 2005) Istilah Maqūsid alSyari'ah, walaupun belum digunakan pada generasi awal islam atau pada masa sahabat dan para tabi'in akan tetapi benih dari konsep Maqāsid alSyari'ah telah disebar pada masa kenabian, hanya saja tumbuh berkembangnya lambat tidak seperti disiplin ilmu yang lainnya semisal ilmu hadis, fiqih, tafsir, tasawuf dan yang lainya dari ilmu yang berkembang dalam khazanah peradaban islam.

Kesimpulan dari definisi yang diutarakan oleh para ulama terutama ulama usul fikih dan fikih yang dimaksud dari Maqāsid al-Syari'ah adalah tujuan utama (nilai universal) yang akan dicapai dari ketetapan hukum baik secara umum maupun secara khusus. Sedangkan dalam usaha menangkap dari tujuan Syari'ah atau hukum harus memperhatikan dalil-dalil atau dasar hukum secara komprehensif dan kemaslahatan manusia. Sebagian ulama berpendapat Maqāsid al-Syari'ah merupakan hikmah dan rahasia dari ketetapan hukum. (Magribi al- 1993) Sementara ulama kontemporer cenderung kepada nilai universal dalam memaknai Maqāsid al-Syari'ah, yaitu: pesan moral dari Tuhan yang akan disampaikan kepada manusia melalui sebuah hukum atau syari'ah. (Daraini al- 2012) Dari uraian tersebut diatas tentang makna Maqāsid al-Syari'ah bisa disimpulkan bahwa Allah Swt yang menurunkan Syari'ah memiliki tujuan yaitu untuk kemaslahatan bagi manusia dan menghindarkan manusia dari kemadharatan baik didunia dan diakhirat.

\section{PEMBAHASAN}

Maqāsid syari'ah dalam sejarah perkembangan pengetahuan umat islam tergolong disiplin ilmu baru, yang muncul dari hasil pengembangan disiplin ilmu Usul Fikih. Walaupun Maqāsid al-Syari'ah munculnya sebagai disiplin ilmu mandiri terbilang baru akan tetapi Maqāsid al-Syari'ah telah ada sejak awal islam atau sejak masa kenabian yang kemudian dipraktekkan oleh para sahabat, tabi'in dan generasi penerusnya hingga sekarang. Para imam madzhab fikih (Syafi'i, abu Hanifah, Ahmad, Malik dan yang lainya) telah menggunakan perangkat Maqāsid al-Syari'ah dalam pengambilan istinbāt hukum pada permasalahan fikih, akan tetapi Maqāsid al-Syari'ah di masa para imam fikih masih menginduk dalam disiplin ilmu usul fikih atau belum menjadi sebuah disiplin ilmu tersendiri.

Untuk mempermudah dalam penelitian bidang sejarah perkembangan ilmu Maqāsid al-Syari'ah dari awal munculnya hingga 
menjadi sebuah disiplin ilmu tersendiri (ilmu Maqāsid al-Syari'ah), maka peneliti membagi periodesasi atau fase perkembangan ilmu Maqāsid alSyari'ah menjadi 3 (tiga) periode atau fase yaitu: periode pertama: masa munculnya essensi dari Maqāsid pada masa awal islam, periode kedua: masa kodifikasi dari Maqāsid yang diprakarsai oleh para ulama, periode ketiga: pada masa ini sebagai masa penyempurnaan dan pengembangan disiplin ilmu Maqāsid dan dijadikanya sebuah disiplin ilmu tersendiri di era-modern.

Periode pertama: Maqāsid al-Syari'ah dalam perkembanganya pada masa sahabat dan generasi seterusnya. Para sahabat merupakan murid rasul yang hidup dan berjuang dengan rasul demi tegaknya islam. Mereka mendapat pengetahuan islam secara langsung dari rasul SAW. tentang hukum dan bagaimana mengambil istinbāt hukum serta berfatwa, tentu rasul juga mengajarkan hikmah-hikmah dari setiap hukum dan tujuan atau Maqāsid dari ditetapkanya sebuah hukum. dari perjalanan sahabat yang bisa diambil contoh dalam permasalahan Maqāsid al-Syari'ah antaranya permasalahan pembukuan al-Qur'an menjadi Mushäf, hal ini terjadi pasca meninggalnya rasul SAW., pada masa khalifah Abu Bakar as-Sidiq sedangkan selesai pembukuan Mushāf pada masa khalifah Utsman ibn Affan. Latar belakang dari pembukuan al-Qur'an ini dikarenakan para penghafal al-Qur'an banyak yang gugur pada pertempuran Yamamah, yang menyebabkan kekhawatiran Umar ibn Khatab tentang hilangnya al-Qur'an ditengah-tengah umat islam. Hal ini (pembukuan al-Qur'an menjadi Mushäf) belum pernah dilakukan pada masa rasul, akan tetapi dilakukan para sahabat dengan tujuan kemaslahatan umat islam. (Syandidi al- 2008) dalam hal ini imam alSyatibi menggolongkan perbuatan para sahabat tersebut kedalam permasalahan (Hifdz ad-Din) yaitu upaya menjaga agama.

Pada masa Umar ibn Khatab, ada kejadian yang cukup terkenal dikalangan ulama terutama ulama fiqih, yaitu kejadian pencurian yang khalifah (Umar ibn Khatab) mengetahui perbuatan tersebut, akan tetapi khalifah tidak menjatuhkan hukuman (mempunish) dengan hukuman potong tangan, dalam hal ini tentu saja khalifah mengetahui hukuman bagi seorang yang mencuri, dan tentunya khalifah mengetahui konsekuensi hukum yang tidak diterapkan di masa kepemimpinanya. Hal ini (kejadian pada masa Umar ibn Khatab tentang pencurian yang tidak dihukum) setelah dikaji bahwa khalifah Umar telah melaksanakan islam secara benar ketika tidak menjatuhkan hukuman potong tangan kepada pencuri karena pada saat itu sedang dilanda musim paceklik atau susah bahan makanan, yang mana pada saat itu banyak yang kelaparan dan kekurangan bahan makanan. (qal Aji 1989) apa yang dilakukan oleh Khalifah Umar ibn Khatab tersebut merupakan bagian dari penerapan Maqāsid al-Syari'ah, yaitu menghindarkan dari kelaparan (untuk 
menghindarkan dari bahaya kebinasaan) sehingga orang masih bisa bertahan hidup. Apa yang dilakukan khalifah Umar tersebut dalam perspektive imam al-Syatibi yaitu tergolong Hifdz Nafs (manjaga jiwa), walaupun tujuan dari diterapkan hukum potong tangan juga bagian dari Maqāsid al-Syari'ah (Hifdz al-Mal atau menjaga harta), akan tetapi Hifdz anNafs dikedepankan terlebih dahulu dari pada Hifdz al-Mal.

Fatwa dan istinbat hukum yang menekankan pada Maqāsid alSyari'ah (rahasia dan hikmah) dari syari'ah islam juga dilakukan generasi setelahnya, yaitu pada masa khalifah Umar ibn Abdul Aziz yang memprakarsai kodifikasi hadis atau sunnah. Kebijakan Umar ibn Abdul Aziz ini ditinjau dari kacamata Maqāsid al-Syari'ah adalah agar ajaran islam (yang bersumber dari hadis nabi) tidak hilang atau punah seiring dengan meninggalnya para penghafal hadis. (Raisuni al- 2010) kebijakan Umar ibn Abdul Aziz ini dalam kajian Maqāsid al-Syari'ah bagian dari Hifdz ad-Din atau bagian dari menjaga agama. Sedangkan generasi selanjutnya yaitu generasi para imam fikih (Abu Hanifah, Malik, Syafi'i, Ahmad dan yang lainya) mengembangkan disiplin ilmu fikih dengan menggunakan instrumen ilmu usul fikih yang didalamnya terdapat pembahasan tentang Maslāhah dan Madhārat, Syad al-Dharā'i, Istihsān, Mashālih al-Mursālah dan yang lainya yang di dalamnya terdapat bagian dari konsep Maqāsid al-Syari'ah akan tetapi masih bersifat parsial (belum menjadi teori Maqāsid al-Syari'ah secara utuh) dikarenakan ilmu ini masih menginduk pada disiplin ilmu usul fikih. (Ubaidi al- 1992) pada generasi para imam madzhab ini merupakan awal munculnya ide dan pemikiran tentang teori Maqāsid al-Syari'ah akan tetapi ide atau pemikiran tersebut masih bersifat pendukung dalam ilmu usul fikih, sehingga sampai sekarang ide dan teori maslāhah dan madhārat dikenalnya bagian dari ilmu usul fikih bukan ilmu Maqāsid. Pada masa imam madzhab istilah Maqāsid belum digunakan dalam musthalahāt al-fiqīyah, istilah Maqāsid dalam penjelasan literatur fikih baru digunakan oleh imam Haramain (al-Imam al-Juwaini) dalam beberapa pembahasan dalam pada kitabnya, akan tetapi dalam kitabnya imam Juwaini tidak menyebutkan istilah Maqāsid alSyari'ah secara tegas, istilah atau lafadz yang dipakai menggunakan lafadz al-Ghard atau terkadang menggunakan al-Qasd.

Periode kedua: masa pengkodifikasian Maqāsid al-Syari'ah, pada periode ini walaupun ilmu Maqāsid masih menginduk dengan disiplin ilmu yang lainya yaitu ilmu usul fikih akan tetapi para ulama sudah lebih banyak berbicara dan membahas serta mempraktekkan ilmu Maqāsid secara mendalam terutama dalam hal berfatwa dibidang fikih. Sudah menjadi catatan sejarang bahwa pada masa awal berdirinya peradaban islam sampai dipertengahan perjalanan peradaban islam disiplin ilmu fikih merupakan salah satu disiplin ilmu yang mengalami perkembangan sangat pesat sehingga banyak menelurkan ilmuwan yang ahli dibidang 
fikih, secara tidak langsung perkembangan ilmu usul fikih juga mengalami perkembangan yang dinamis, sehingga banyak para ilmuan yang merekonstruksi ulang tentang teori-teori usul fikih misalnya teori usul fikih yang dikembangkan imam al-Syafi'i direkonstruksi dan dikembangkan lagi oleh imam Haramain, dari imam Haramain dikembangkan lagi oleh muridnya imam al-Ghazali dan seterusnya, yang artinya ilmu senantiasa akan mengalami perkembangan dan perubahan, begitu juga ilmu Maqāsid. (Dib ad- 1992) imam al-Juwaini mengembangkan teori Maqāsid dengan mengklasifikasikan Maqāsid menjadi tiga pokok pembahasan Maqāsid yaitu: al-Dharūrīat, al-Hājīat dan al-Tahsiniyat. (Dib ad- 1992) sementara al-Ghazali melengkapi dari teori yang telah ditelurkan oleh gurunya (imam al-Juwaini) dalam al-Dharūrīat diperinci lagi menjadi lima pokok pembahasan atau yang disebut dengan al-Kuliyah al-Khamsah (hifdz ad-Dìn, an-Nafs, An-Nasl, al-Māl dan al-ard) yang memperjelas dari Maqāsid dalam hal al-Dharūrīah. (Ghazali al-1993) al-Imam ar-Razi (606 H.) lebih memperjelas dan memberikan modifikasi dari teori para pendahulunya (imam Haramain dan imam al-Ghazali) dalam pembagian al-Dharūrīah, al-Häjīah dan Tahsīnìyah, memberikan tambahan Qat'i dan Dzańi (pengambilan dalil dari sumber Mutawātir dan ahād), selain itu ar-Razi juga membagi Maslāhāh menjadi dua yaitu: Maslāhāh bagi manusia di dunia dan Maslāhāh bagi manusia di akhirat. (Ulwani al- 1968) datang setelah imam ar-Razi imam al-Amidi (Saifuddin al-Amidi 631 H.) beliau menggabungkan empat kitab usul fiqih karya ulama sebelumnya yaitu: kitab al-Mustasyfā karya imam al-Ghazali, alBurhān karya imam al-Juwaini, kitab al-Mustāmad karya imam Abu Husain al-Basri dan kitab yang dikarang oleh Qadhī abdul Jabar dengan sebutan al-Amd. Imam Amidi mampu memberikan definisi tentang Maqāsid dengan cara menarik kesimpulan dari berbagai pemikiran para pendahulunya dengan mengatakan bahwa tujuan dari Syari'ah adalah mewujudkan kemaslahatan dan menghindarkan atau mencegah kemadharatan, walaupun menelurkan pemikiran tentang definisi Maqāsid imam Amidi masih memegang perinsip dan teori para pendahulunya dalam hal pembagian Maslāhāh (Maslāhāh di dunia dan Maslāhāh di akhirat). (Jabah-ji 1990) Dalam perkembangan dan aplikasi fikih imam Amidi mentarjih hasil istinbāt hukum yang menggunakan instrumen Qiyās dan Maqaāid al-Syari'ah apabila terdapat kesimpulan hukum yang saling bertentangan dengan menggunakan prioritas dalam Maqāsid al-Syari'ah yaitu: al-Dharūrīah, al-Hājīah atau al-Tahsinīah.

Izzuddin Abdul Salam (660 H.) dari generasi setelahnya memberikan kontribusi dalam Maqāsid al-Syari'ah dengan meletakkan dasar foundasi Maqasid al-Syari'ah dan Qaidah-qaidah yang berhubungan dengan Maslāhāh dan Māihārāt dalam karyanya "Qawāid al-Ahkām fī Mashālihul Anām". (Miftah al- 2005) selain itu menurut Izzuddin Abdul 
Salam bahwa obyek kajian dari ilmu Maqāsid al-Syari'ah adalah tentang Maslāhāh dan Mafsādāh. Dalam penekananya bahwa Syari'ah islamiyah diturunkan untuk kemaslahatan manusia dan menghindarkan manusia dari kemadharatan. Sedangkan imam al-Qurafi (Syihabuddin al-Qurafi 685 H.) yang juga satu masa dengan imam Izzuddin Abdul Salam lebih memperdalam tentang pembahasan Maqāsid al-Syari'ah dengan memberikan atau meletakkan metodologi dan rumusan dalam Maquasid yaitu dengan metode Istigrā'i, beliau menerangkan bahwa tidak ada Maslāhāh yang tidak terdapat didalamnya Mafsādāh, dengan memberikan argumentasi bahwa dalam Khamer itu terdapat dosa dan manfaat, akan tetapi dosanya lebih besar (Q.S. al-Baqarah: 219) hipotesa dari ayat tersebut, bahwa "Maslāhāh bisa bercampur dengan Mafsādāh". (Qurafi al1973) teori Maqāsid al-Syari'ah pada fase kedua ini masih dalam catatan pengembangan ilmu usul fikih belum terfokus kedalam bingkaian disiplin ilmu Maqāsid al-Syari'ah secara mandiri, para imam ahli fikih dan usul fikih belum membingkai kedalam sebuah disiplin ilmu tersendiri, sehingga pada masa ini belum ada definisi secara baku dan disetujui oleh ilmuwan tentang Maqāsid al-Syari'ah begitu juga obyek kajian, sementara Ibn Taimiyah (728 H.) agak berbeda dalam pembahasan Maqāsid, beliau lebih kepada aplikasi bukan hanya sekedar teori, banyak hasil ijtihad beliau yang menggunakan instrumen Maqāsid al-Syari'ah yang beliau tuliskan dalam karyanya (kitab Majmūk al-fatāwā), (Ahmad 2000) selain itu beliau memberikan tambahan dalam teori Maqāsid (tujuan dari hukum islam) tidak hanya terbatas pada al-Kuliyah al-Khamsāh (lima hal: menjaga agama, jiwa, keturunan, harta dan akal) tetapi beliau memberikan tambahan kaidah Mukhālafāh al-Musriqīn, al-I'tiläf, Adl wā adām al-Dhūlm, al-Taisìr wā Raf'u al-Kharāj. (Khirzallah 2005) sedangkan muridnya ibn Qayim al-Jauziyah (751 H.) dalam pengembangan ilmu Maqāsid, ibn Qayim banyak mencurahkan perhatianya dalam hal illäh dan hikmah dari sebuah hukum syari'ah. (Jauziyah al- 1991)

Periode ketiga: Maqāsid sebagai disiplin ilmu mandiri. Pada fase ini ilmu Maqāsid al-Syari'ah sudah menjadi sebuah disiplin ilmu tersendiri (terlepas dari induknya yaitu ilmu usul fikih), dengan imam al-Syatibi (790 H.) dikenal sebagai peletak disiplin ilmu Maqāsid al-Syari'ah, nama lengkapnya Abu Ishaq Ibrahim bin Musa bin Muhammad al-Lakhmi alGharnati, karya yang monumental tentang Maqāsid al-Syari'ah yaitu kitab al-Muwāfaqāt. Syatibi banyak menyumbangkan pemikiranya dalam hal istimbat hukum syari'ah dengan metode dan pendekatan disiplin ilmu yang baru, karena selama ini para ulama fikih dalam mengambil keputusan hukum (fatwa) menggunakan pendekatan ilmu usul fikih. Syatibi menawarkan metode baru yaitu metode menangkap pesan Tuhan yang terdapat dalam teks-teks keagamaan dengan pendekatan Maqāsid alSyari'ah. (Ubaidi al- 1992) teori ini dilatarbelakangi kegelisahan imam al- 
Syatibi yang menganggap bahwa ilmu usul fikih begitu lamban dalam memberikan respon atau jawaban dari permasalahan-permasalahan baru yang muncul di tengah-tengah masyarakat (usul fikih kurang bisa menjawab problematika dalam realita sosial di masyarakat), sehingga fikih membutuhkan pendekatan disiplin baru dalam usaha menghasilkan kesimpulan hukum yang tepat dan cepat. Paradikma berfikir yang belum pernah dirumuskan oleh para pendahulunya ini yang menjadikan imam al-Syatibi dijuluki sebagai bapak peletak ilmu Maqāsid al-Syari'ah. Akan tetapi walaupun ilmu Maqāsid sudah dijadikan sebuah disiplin ilmu yang mandiri (terpisah dari ilmu usul fiqih) sepeninggal al-Syatibi diskursus Maqāsid al-Syari'ah mengalami kefakuman dalam artian tidak banyak para sarjana muslim yang mengkajinya sebagai sebuah disiplin ilmu yang memberikan pembahasan yang menarik untuk dikaji, sehingga ilmu ini seakan musnah karena tidak ada yang mengembangkan teori Maqāsid (tidak ada penerus dari imam al-Syatibi). Sampai muncul ulama dari universitas al-Zaitun Tunisia (Muhammad Thahir ibn Asyur 1393 H. / 1973 M.) yang berhasil mentransformasi ilmu usul fikih yang dipandangnya terlalu sempit apabila dipakai sebagai instrumen hukum dalam memecahkan permasalahan umat yang lebih plural terutama di zaman modern menjadi nilai ajaran yang universal. (Misawi al- 2001) ibn Asyur berpandangan bahwa era-modern menuntut umat saling berinteraksi antar agama, etnis dan beragam tradisi dan budaya menjadikan ilmu usul fiqih kurang kondusif, sehingga perlu adanya pembaharuan dalam format hukum demi menyesuaikan zaman, selain itu mengatakan dengan tegas bahwa ilmu Maqāsid al-Syari'ah adalah disiplin ilmu tersendiri sudah tidak menginduk kepada ilmu usul fiqih. Keberhasilan ibnu Asyur dalam teori Maqāsid al-Syari'ah ini menjadikan beliau dijuluki bapak Maqasid al-Syari'ah al-Islamaiyah setelah Imam alSyatibi. (Turki al- 1990) Core pemikiran ibnu Asyur dalam disiplin ilmu Maqāsid al Syari'ah yaitu: meletakkan foundasi Maqasid yang cakupanya lebih luas sehingga memiliki nilai universal, tidak hanya diterima di lingkup umat islam tetapi bisa diterima masyarakat internasional dari berbagai agama. Foundasi Maqāsid yang dirumuskan ibnu Asyur antaranya: Fitrah, Toleransi, Kebebasan dan Hak Asasi (Keadilan). Sejalan dengan al-Fasi (ulama yang sezaman dengan ibnu Asyur) yang juga memiliki perhatian terhadap disiplin ilmu Maqāsid al-Syari'ah yaitu: al-Fasi (Muhammad Alal al-Afasi) beliau banyak menekankan pada permasalahan kontemporer (permasalahan demokrasi, poligami, gender, hak dan kebebasan) Maqāsid yang diusungnya adalah keadilan dan maslahah. (Magribi al-, Maqasid al-Syari'ah wa Makarimuha 1993) Sedangkan dalam pembahasan al-Fasi lebih menekankan pada nilai-nilai humanis dan realita empiris dari pada hanya sekedar teoritis. Hal ini dilatarbelakangi sosok al-Fasi sendiri yang aktif sebagai seorang politisi 
(banyak turun kemasyarakat berinteraksi secara langsung dengan masyarakat), aktifitas dan kesibukanya banyak memberikan pengaruh pada pemikiranya sehingga al-Fasi menerima konsep demokrasi yang berkembang dinegara-negara barat yang menganut dualisme kekuasaan (kekuasaan Tuhan dan kekuasaan rakyat), hukum di tangan Tuhan artinya Tuhan tempat bergantung dari segala persoalan kehidupan, hukum di tangan rakyat artinya rakyat yang berhak menentukan ulil amri atau pemimpin dengan tata cara yang berlaku pada masyarakat. (Magribi al-, Maqasid al-Syari'ah wa Makarimuha 1993) selain permasalahan demokrasi al-Fasi juga gencar menyuarakan isu tentang gender dengan memberikan ketentuan atau persyaratan yang berat bagi pelaku poligami, pemikiran al-Fasi dan ibn Asyur lebih terbuka karena melibatkan wawasan dari khasanah keilmuan barat yang mengandung nilai universal, seperti nilai humanisme dan demokrasi, sehingga menjadikan konsep Maqāsid al-Syari'ah lebih inklusif.

Maqāsid al-Syari'ah pada generasi melenial sekarang telah mendapatkan tempat di hati para pengembang ilmu syari'ah dengan berbagai improvisasi pengetahuan seperti apa yang dikembangkan oleh Jasser Auda dengan konsep Maqāsid al-Syari'ah sebagai sistem dalam filsafat hukum. (Auda 2007) dengan banyak melibatkan berbagai macam disiplin ilmu (memasukkan unsur pengetahuan umum di samping pengetahuan agama) Jasser Auda lebih luas dalam memamdang permasalahan sehingga bukan hanya permasalahan agama saja yang menjadi perhatian akan tetapi isu-isu dan permasalahan modern di samping memperhatikan turās islām. (Abdullah Januari-Juni 2011) konsep yang ditawarkan bukan hanya Maqāsid klasik yang hanya menjaga, akan tetapi mengembangkan, mewujudkan keadilan, hak asasi, kebebasan dan menyeluruh dalam 6 (enam) landasan antaranya: Kognitif, Menyeluruh, Keterbukaan, Keterkaitan, Multidimensi dan Berorientasi pada tujuan. (Auda 2007)

Perjalanan yang cukup panajang dari awal penyemaian benih Maqāsid hingga sekarang banyak mengalami perubahan paradigma dari rumpun keilmuan fikih klasik sampai pengetahuan umum modern, dari perangkat berfikir ekslusif hingga pemikiran yang inklusif, dari usul fikih hingga filsafat sistem.

\section{Urgensi Maqasid al-Syari'ah}

Ilmu Maqāsid al-Syari'ah merupakan salah satu disiplin ilmu yang sangat dibutuhkan terutama dalam hal berfatwa masalah hukun, ilmu Maqāsid al-Syari'ah merupakan bagian dari perangkat atau persyaratan yang harus dipenuhi bagi seorang Mujtahid, karena dengan ilmu ini seorang Mufti akan mempertimbangkan tujuan dari fatwa. Imam Syatibi dalam bukunya mengatakan "bagi siapa saja yang berijtihad, mustahil 
baginya mengesampingkan ilmu Maqāsid al-Syari'ah, oleh karena seorang mufti terkadang melakukan kesalahan dalam berijtihad disebabkan tidak memperhatikan permasalahan Maqāsid". (Auglhu 2005) imam Syatibi mengumpamakan ilmu Maqasid bagaikan ruh dari segala ilmu, orang hidup tanpa Maqāsid bagaikan orang hidup tanpa ruh, orang berdakwa tanpa Maqāsid bagaikan berdakwah tanpa ruh yang mampu memberikan spirit, fikih tanpa Maqāsid al-Syari'ah tidak ada nilainya karena hakekat fikih adalah memahami rahasia, hikmah dan tujuan dari syari'ah yang Allah Swt turunkan. Syah Waliyullah Kandahlawi menempatkan ilmu Maqāsid al-Syari'ah sebagai ilmu yang paling muliya di antara ilmu syar'I karena di dalam ilmu ini membahas rahasia-rahasia Allah Swt, hujjah atau alasan Allah Swt menurunkan perintahNya dan laranganNya. (Raisuni al2010)

Permasalahan penafsiran teks-teks keagamaan apabila mengesampingkan dari Maqāsid al-Syari'ah juga akan menyebabkan pemahaman yang salah sehingga akan terjerumus kepada sikap ifrad dan tafrid dalam beragama, hal ini tercatat dalam sejarah peradaban islam yang mana sebagian umat islam salah dalam menafsirkan pesan yang terdapat dalam al-Qur'an sehingga menyebabkan perpecahan dan pertumpahan darah seperti yang terjadi pada sekelompok aliran Khawarij yang mengkafirkan saudaranya sesama muslim. Segala pengetahuan yang tidak disertai dengan dasar pengetahuan Maqāsid akan terasa kering kurang mampu memberikan pencerahan dalam hal pemikiran, fikih yang tanpa didasari dengan pengetahuan Maqāsid al-Syari'ah hanya akan terlihat sebuah teori yang kaku dalam praktiknya karena tidak disertai pengetahuan hikmah dan tujuan dari disyari'atkan sebuah hukum. Tanpa ilmu Maqāsid al-Syari'ah kita hanya akan tau pelarangan mencuri dan hukuman bagi pencuri, kita tidak akan tau hikmah, rahasia dan tujuan dari hukuman potong tangan bagi pencuri, padahal dibalik hukum potong tangan syari'at memberikan pesan bahwa harta itu dilindungi oleh agama. Sebaliknya sesuatu yang dilatarbelakangi dengan pengetahuan yang berhubungan dengan tujuan, hikmah dan rahasia akan menjadikan seorang lebih sabar dalam mengerjakanya dan akan lebih sungguhsungguh karena dengan mengerti menjadikan seorang sadar akan hakekat apa yang dikerjakan.

\section{Manfaat mempelajari Maqasid al-Syari'ah}

Maqāsid al-Syariah memiliki manfaat yang besar bagi siapa saja yang mendalami permasalahan hukum terutama hukum syari'ah atau fikih. Diantara manfaat dari Maqāsid al-Syari'ah yaitu mampu memberikan solusi bagi permasalahan yang bersifat universal misalnya dalam beragama dilarang memaksakan keyakinan, secara nilai universal bahwa pesan agama bisa ditangkap dengan kebebasan dalam berkeyakinan, di 
sisi lain agama melarang atau menghukum orang yang murtad dari agamanya. Pesan yang bisa ditangkap adalah agama mewajibkan menjaga agama dari hal-hal yang dapat merusak agama. Atau secara Maqāsid alSyari'ah hukuman bagi orang yang murtad bertujuan untuk menjaga agama dari kerusakan.

Manfaat memahami Maqāsid al-Syari'ah bagi seorang yang mendalami hukum islam, akan mampu menangkap hikmah dari disyari'atkan sebuah hukum baik secara parsial atau universal misalnya pelarangan minum khamer, hukum potong tangan bagi yang mencuri dan sebagainya. Manfaat lain dari memahami Maqāsid al-Syari'ah menjadikan seorang mampu memadukan permasalahan ketika awal islam (masa rasul, sahabat dan tabi'in) dengan permasalahan kontemporer atau kekinian. Kemampuan ini menjadikan seorang Mujtahid memiliki kompetensi dalam mengeluarkan fatwa tentang hukum islam yang berhubungan dengan permasalahan kontemporer atau permasalahan hukum kekinian.

Maqāsid al-Syari'ah juga membantu mentarjih dalam permasalahan perbandingan hukum dengan cara memilih atau memperhatikan tujuan dari syari'ah (Maqāsid al-Syariah) untuk mewujudkan kemaslahatan dan mencegah dari kemadharatan, contoh keputusan khalifah Umar ibn Khatab tidak menghukum pencuri yang kelaparan yang bisa menyebabkan kepada kematian. Dalam hal ini Umar lebih mengutamakan hifdz nafs dari pada hifdz māl. (Ramli 2016) sedangkan bagi para penetili di bidang hukum, ilmu Maqasid al-Syari'ah akan banyak membantu dalam memahami illah dari sebuah hukum syar'I sehingga dalam perumusan sebuah hukum lebih tepat, atau dengan mengerti illah dari sebuah hukum akan terhindar dari kesalahan fatal dalam pengambilan kesimpulan (istinbat) hukum. (Sabri 2015) manfaat dari ilmu Maqāsid al-Syari'ah masih sangata banyak, Maqāsid al-Syari'ah mampu menghiasi para ilmuan yang banyak bergelut dalam bidang hukum dan ilmu syar'i.

\section{KESIMPULAN}

Ilmu Maqāsid al-Syari'ah tergolong disiplin ilmu yang baru dalam khasanah pengetahuan islam, ilmu ini dulunya masih menginduk kedalam ilmu fikih dan usul fikih yang kemudian terpisah menjadi disiplin ilmu tersendiri. Ilmu Maqāsid al-Syari'ah merupakan perangkat penting bagi seorang mujtahid yang selalu memiliki ketersinggungan dengan permasalahan hukum terutapa permasalahan kontemporer, karena perangkat ini (ilmu Maqāsid al-Syari'ah) mampu menghubungkan teks-teks masa lampau dengan permasalahan yang sedang dihadapi sekarang sehingga fikih islam akan terlihat lebih fleksibel usaha merelevansikan ajaran islam dengan zaman sekarang. Begitu juga sebaliknya bagi seorang mujtahid yang mengabaikan ilmu Maqāsid al-Syari'ah maka apabila 
berfatwa atau mengambil istinbat hukum akan terlihat bahwa ajaran islam kurang luwes dalam mengikuti zaman, hukum islam tidak bisa memberikan inspirasi terhadap perkembangan zaman dan bahkan ajaran atau hukum islam menjadi penghambat dari perkembangan.

Paradigma Maqāsid al-Syari'ah mengalami pergeseran secara formatnya luarnya saja akan tetapi essensi dari pesan syari'ah masih tetap. Pergeseran bentuk Maqāsid al-Syari'ah ini terpengaruh dengan yang namanya konsep ruang dan waktu, atau lebih jelasnya terjadinya perubahan zaman yang dipengaruhi faktor pengetahuan dan teknologi sehingga mempengaruhi pola dan cara berfikir manusia pada zamanya masing-masing, perubahan ini yang melatarbelakangi pentingnya kita merubah metode berfikir lama menjadi metode baru (metode ilmu usul fikih menuju ilmu Maqāsid al-Syari'ah) sedangkan yang menjadi alasan kuat kenapa kita harus melakukan pergeseran metode berfikir (dari usul fikih menuju Maqāsid al-Syari'ah) karena sekarang kita hudup di masyarakat yang majemuk (plural) sudah tidak cocok lagi menggunakan perangkat usul fikih yang lahir di tengah-tengah masyarakat monokultur. (Misawi al2001) Sedangkan pergeseran essensi dari pesan syari'ah pada awal islam lebih mengkampanyekan istilah Rahmātan lil älamīn, kemudian muncul istilah Dzarūriyāh, Häjiyāh dan Tahsīniyāh, sering dengan perkembangan zaman dan pengetahuan istilah tersebut meningkat menjadi kuliyah alKhamsah, pada masa sekarang atau era-modern meningkat menjadi lebih luas sehingga pesannya lebih universal mulcul istilah adil atau keadilan, manusiawi atau kemanusiaan dan demokratis. (Auda 2007) dari sejarah paradigma Maqāsid al-Syari'ah kita dapat pelajaran bahwa pengetahuan besifat dinamis dan tidak absolute karena adanya pengaruh perubahan ruang dan waktu (taghāyūr bi taghoyurī ahwāl wal azmināh).

\section{DAFTAR PUSTAKA}

Abdullah, Muhammad Amin. Hak Kebebasan Beragama dan Berkeyakinan; Pendekatan Filsafat Sistem dalam Usul Fikih Sosial. Magelang: ejournal.umm.ac.id, Januari-Juni 2011.

Ahmad, Yusuf Muhamad al-Badawi. Maqasid al-Syari'ah Inda ibn Taimiyah. Cairo: Dar al-Nafais, 2000.

Alim al-, Yusuf Hamid. al-Maqasid al-Ammah li al-Maqasyid al-Syari'ah alIslamiyah. Cairo: Dar al-Hadis, 1991.

Auda, Jasser. Maqasid al-Shariah as Philosophy of Islamic Low; a System Approach. London: The International Institute of Islamic Low, 2007.

Auglhu, Ali Bardaq. Maqasid al-Syari'ah al-Islamiyah wa Taudhifuha li Khalli al-Masyakil al-Muasyirah. Mesir: Maljil A'la Lisyu'un al-Islamiyah, 2005. 
Daraini al-, Fathi. Khasais al-Tasyri' al-Islam fi al-Siyasah wa al-Hukmi. Cairo: Mu'asasah al-Risalah, 2012.

Dib ad-, Abdul Adhim Muhammad. al-Burhan fi Usul Fiqih li al-Juwaini. Mansurah: Dar Wafaq, 1992.

Ghazali al-, Abu Hamid Muhammad ibn Muhammad. al-Mustasfa min Ulum al-Ususl. Beirut: Muassasah ar-Risalah, 1993.

Jabah-ji, Umar Muhammad. Maqasid al-Syari'ah al-Islamiyah. Beirut: Dar Kutub al-Ilmiyah, 1990.

Jauziyah al-, Ibn Qayim. I'lam al-Muwaqi'in. Beirut: Dar Qutub Ilmiyah, 1991.

Khirzallah, Abdul Qadir. al-madkhal Ila Ilm Maqasid al-Syari'ah. Riyad: Ibn Rusd, 2005.

Magribi al-, al-Ala al-Fasi. Maqasid al-Syari'ah wa Makarimuha. Beirut: Dar al-Gharb, 1993.

Mandhur, Muhammad ibn Hakam ibn. Lisan al-Arab. Vol. II. beirut: dar Ihya' al-Arabi, 1998.

Miftah al-, Farid ibn Ya'kub. Maqasid al-Syari'ah al-Islamiyah fi dhau'i Mustajad al Asri. Mesir: Majlis 'Ala li su'un al-Islamiyah, 2005.

Misawi al-, Muhammad Thahir. Tahqiq Maqasid al-syari'ah al-Islamiyah li Fadhilah Ustadz Muhammad thahir ibn Asyur. Kuala Lumpur: Dar Ilm lil Intaj, 2001.

qal Aji, Muhammad. Mausu'ah fiqih Umar . Beirut: Dar an-Nafais, 1989.

Qurafi al-, Syihabuddin abu Abas. Syarhu al-Tanqih al-Fuhul. Cairo: alSyarikah al-Thaba'ah al-Faniyah al-Muttahidah, 1973.

Raisuni al-, Ahmad. Madkhal il Maqasid al-Syari'ah. Cairo: Dar al-Kalimah, 2010.

Ramli, Anggraini binti. Alaqah Baina al-Usul Fiqih wa Maqasid al-Syari'ah wa Da'wah ila Ta'sis Ilmi al-Maqasid. Des. Vol. vol. XV. . no. 2, vols. Madzhab, 2016.

Sabri, Mas'ud. Bidayah al-Maqasid ila Ilmi al-Maqasid. Dimask: Rabithah Ulam al-Syuriyin, 2015.

Syandidi al-, Ismail. al-Qaidah dar'u al-Mafasid wa jalbu al-Mashalih wa atsar fi fiqih islam. dimasq: dar al-Jami'ah al-Jadidiah, 2008.

Syatibi al-, Abu Ishaq. al-Muwafaqat. Beirut: Dar al-Ma'rifah, 2001.

Turki al-, Abdul Majid. al_syatibi Wa Ijtihad al-Tasri' al-Mu'asir. Beirut: Dar al-Ijtihad, 1990.

Ubaidi al-, Hammadi. al-Syatibi wa Maqasid al-Syari'ah. Dimasq: Dar Qutaibah, 1992.

Ulwani al-, Thaha Jabir. al-Mahsul min Ulum al-Usul li ar-Razi. Riyad: Imam ibn Su'ud, 1968. 